\title{
THE IMPACT OF THE GENE VARIANTS FV LEIDEN, FII G20210A, MTHFR C677T AND PAI-1 4G/5G ON PREGNANCY LOSS IN WOMEN FROM CENTRAL SERBIA
}

Gordana M. Sosic ${ }^{1}$, Snezana Sretenovic ${ }^{2}$, Danijela Radivojevic ${ }^{3}$, Nikola Jovic ${ }^{4}$, Mirjana Varjacic ${ }^{4,5}$ ${ }^{1}$ Department for Cytogenetic Diagnosis, Clinic of Obstetrics and Gynecology, Clinical Center Kragujevac, Kragujevac, Serbia ${ }^{2}$ Clinic of Hematology, Clinical Center Kragujevac, Kragujevac, Serbia

${ }^{3}$ Laboratory for Medical Genetics, Institute for Health Protection of Mother and Child of Serbia "Dr. Vukan Cupic", Belgrade, Serbia ${ }^{4}$ University of Kragujevac, Faculty of Medical Sciences, Kragujevac, Serbia

${ }^{5}$ Department of Pathology of Pregnancy, Clinic of Obstetrics and Gynecology, Clinical Center Kragujevac, Kragujevac, Serbia

\section{UTICAJ GENSIIH VARIJANTI FV LEIDEN, FII G20210A, MTHFR C677T I PAI-1 4G/5G NA GUBITKE TRUDNOĆA KOD ŽENA IZ CENTRALNE SRBIJE}

Gordana M. Šošić ${ }^{1}$, Snežana Sretenović ${ }^{2}$, Danijela Radivojevićs ${ }^{3}$ Nikola Jović ${ }^{4}$, Mirjana Varjačićc, 5

${ }^{1}$ Odsek citogenetske dijagnostike, Klinika za ginekologiju i akušerstvo, Kliničkog centra Kragujevac, Kragujevac, Srbija ${ }^{2}$ Klinika za hematologiju, Klinički centar Kragujevac, Kragujevac, Srbija

${ }^{3}$ Laboratorija za medicinsku genetiku, Institut za zdravstvenu zaštitu majke i deteta Srbije „dr Vukan Čupić“, Beograd, Srbija

${ }^{4}$ Univerzitet u Kragujevcu, Fakultete medicinskih nauka, Kragujevac, Srbija

Odeljenje patologije trudnoće, Klinički centar Kragujevac, Kragujevac, Srbija

\section{ABSTRACT}

Thrombophilia is a condition of enhanced functionality of the haemostatic system with an increased tendency for thrombosis, and it can be a congenital, acquired, or complex defect. Pregnancy can be the cause of acquired transitory thrombophilia, which may lead to complications if inherited thrombophilia is also present.

The aim of this study was to determine the genetic structure of the population based on the frequency of the gene variants factor V Leiden G1691A, factor II G20210A, methylenetetrahydrofolate reductase C677T, and plasminogen activator inhibitor-1 4G/5G, as well as to investigate the predictive value of these gene variants in repeated miscarriages.

The study included 87 female patients from Central Serbia with an average age of $32.7 \pm 4.5$ years with inherited thrombophilia and previous miscarriages, with or without intrauterine foetal death. The exclusion criteria included the existence of gynaecological and infectious aetiology and the deficit of factors important for the coagulation process.

The resulting genotypes were in Hardy-Weinberg equilibrium. The frequency of genotypes with mutated alleles was signifcantly higher in this group of patients than in the control group for all variants except factor II G20210A. The most commonly mutated alleles were the plasminogen activator inhibitor-1 4G allele (0.61) and methylenetetrahydrofolate reductase $T$ allele (0.47). Double mutation of plasminogen activator inhibitor-1 4G/5G and methylenetetrahydrofolate reductase C677T was dominant in patients with recurrent pregnancy loss (46.15\%).

The presence of a combination of genetic variants of the plasminogen activator inhibitor-1 4G/5G and methylenetetrahydrofolate reductase C677T is a significant predictor of spontaneous abortions in women with inherited thrombophilia in Central Serbia.

Keywords: pregnancy complications, FV Leiden, FII G20210A, MTHFR C677T, PAI-1 4G/5G

\section{SAŽETAK}

Termin trombofilija se upotrebljava za urođene, stečene $i$ kompleksne poremećaje hemostaznog sistema kod kojih postoji sklonost ka trombozama. Stečeni prolazni razlog trombofilije je trudnoća koja zajedno sa urođenom trombofilijom može dovesti do komplikacija.

Cilj ove studije je utvrditi genetičku strukturu populacije na osnovu genskih varijanti za faktor V Leiden G1691A, faktor II G20210A, metilen tetrahidrofolat reduktazu C677T $i$ inhibitor aktivatora plazminogena -1 4G/5G i ispitati prediktivnu vrednost ovih genskih varijanti u odnosu na ponovljene spontane pobačaje.

Studijom je obuhvaćeno 87 pacijentkinja sa teritori-

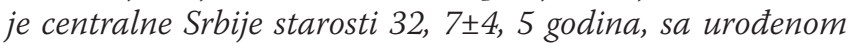
trombofilijom $i$ prethodnim spontanim pobačajima, $i$ sa ili bez intrauterine smrti fetusa. Isključujući kriterijumi su bili postojanje ginekološke ili infektivne etiologije spontanih pobačaja ili deficit faktora važnih u procesu koagulacije $i$ antifosfolipidni sindrom.

Dobijeni genotipovi su bili u Hardi-Vajnbergovom ekvilibrijumu. Frekvence genotipova sa mutiranim alelima su bile značajno više za sve varijante, osim za faktor II G20210A u grupi ispitanica u odnosu na kontrolu. Najčešće prisutni mutirani aleli su bili $4 G$ alel za inhibitor aktivatora plazminogena -1 $(0,61) i$ T-alel za metilen tetrahidrofolat redukazu (0, 47). Nosioci dvostrukih mutacija za inhibitor aktivatora plazminogena-1 4G/5G i metilen tetrahidrofolat reduktazu C677T su bili dominatni kod ispitanica sa rekurentnim gubicima trudnoća (46, 15\%).

Prisustvo kombinacije genskih varijanti inhibitor aktivatora plazminogena-1 4G/5G i metilen tetrahidrofolat reduktaze C677T predstavlja značajan prediktor spontanih pobačaja kod žena sa urođenom trombofilijom na teritoriji centralne Srbije.

Ključne reči: komplikacije trudnoće, FV Leiden, FII G20210A, MTHFR C677T, PAI-1 4G/5G.

\section{sciendo}

Ser J Exp Clin Res 2020; 21 (1): 19-25 DOI: 10.1515/SJECR-2017-0070 


\section{ABBREVIATIONS}

FVL- factor V Leiden FII- factor II

MTHFR- methylenetetrahydrofolate reductase PAI-1- plasminogen activator inhibitor-1 SERPINC1 - serpin family C member 1 PROC- protein C PROS1 - protein $S$ AT III- antithrombin III RPL- recurrent pregnancy loss IUGR- intrauterine growth retardation IUFD- intrauterine foetal death PL- pregnancy loss
APCRV - activated protein $C$ resistance $V$ APSy- antiphospholipid syndrome HHC- hyperhomocysteinemia DNA- deoxyribonucleic acid PCR- polymerase chain reaction

A-adenine

G- guanine

C- cytosine T- thymine

FAM- 6-carboxyfluorescein

HEX- hexachloro-fluorescein

HWE- Hardy-Weinberg equilibrium

APC- activated protein C

\section{INTRODUCTION}

In physiological conditions, haemostasis allows the normal flow of blood in blood vessels and prevents and stops bleeding after the vessels suffer any damage. Maintenance of normal haemostasis enables the dynamic balance between antithrombin and prothrombin mechanisms $(1,2)$. Several factors are involved in this process: the vascular endothelium, platelets, coagulation factors, coagulation inhibitors, and the fibrinolytic system (3). Violation of the haemostatic balance can lead to a haemorrhagic or thrombotic disorder. Thrombophilia is a specific condition with an increased tendency towards thrombosis. Disorders in haemostasis, which are related to the occurrence of thrombophilia, may be congenital (occurring due to genetic mutations), acquired (such as antiphospholipid syndrome), or complex (diet or lifestyle habits interact with the genetic predisposition to thrombophilia) (2). The genetic risk factors for thrombophilia include the presence of variants in the genes encoding coagulation inhibitors (SERPINC1, PROC, PROS1), leading to the deficiency of anticoagulant proteins (AT III, protein $\mathrm{C}$, protein $\mathrm{S}$ ); variants in the genes encoding clotting factors (FVL, NM_000130.4: c.1601G>A, p.Arg534Gln and FII G20210A, NM_000506.4: c."97G>A); variants in the genes encoding other members of the fibrinolytic system (PAI-1 4G/5G, NM_000602.4: c.-820_-817G (4_5)); and other genetic polymorphisms that contribute to the occurrence of thrombosis (MTHFR C677T, NM_005957.4: c.665C $>$ T, p.Ala222Val) (2-7).

During pregnancy and puerperium, all three components of Virchow's triad are present: hypercoagulability, venous thrombosis, and injury to blood vessels (8). Hypercoagulability and hypofibrinolysis in pregnancy reduce the risk of blood loss during implantation, placentation, and the third delivery stage (9). The resulting physiological changes during pregnancy may interact with congenital and acquired thrombophilia conditions, therefore increas- ing the risk of thromboembolic complications. Thrombosis of placental blood vessels, which can lead to a heart attack and placental insufficiency, is considered to be the cause of RPL in women with thrombophilia. Additionally, damage to placental vascularization can lead to IUGR, IUFD, placental abruption, and preeclampsia $(10,11)$. The research in this area has shown the importance of appropriate thromboprophylaxis in order to increase the birth rate (11).

The aim of this study was to examine the population genetic structure of patients from the territory of Central Serbia (Šumadija district) where previous unsuccessful pregnancies due to the presence of thrombophilia were recorded. The frequency of the genetic variants FV Leiden, FII G20210A, MTHFR C677T and PAI-1 4G/5G was determined, and the possible association and predictive value of present genetic markers were examined in relation to previous miscarriages.

\section{MATERIAL AND METHODS}

This study included 87 women from Central Serbia diagnosed with thrombophilia in of the past 3 years who were hospitalized at the Clinic of Hematology, Clinical Center Kragujevac, Serbia. The average age of the patients was $32 \pm 4$ years (range, 22 to 41 years). The study was conducted according to the ethical principles of the Declaration of Helsinki and based on the decision of the Ethics Committee of the Institution (No. 01-12294). The inclusion criteria for the study were PL with/without IUFD and the presence of one or more of the following variants: FV Leiden G1691A, FII G20210A, MTHFR C677T, and PAI-1 $4 \mathrm{G} / 5 \mathrm{G}$. The exclusion criteria for this study were the presence of gynaecological or infectious aetiology; protein $\mathrm{S}$, protein C, AT III, or APCRV deficiencies; APSy; or HHC. 
Peripheral blood samples (with $3.8 \%$ sodium-citrate as the anticoagulant) or buccal mucosal cells taken by sterile swabs were used for DNA extraction. Genomic DNA was isolated using the DNA-Sorb-A and DNA-Sorb-B kits (SACACE Biotechnologies, Italy), according to the manufacturer's standard protocol. The different solutions included in the kits (lysis, washing, sorbent and DNA eluent) isolated DNA of the desired purity and concentration and ready for use in further molecular genetics analysis.

The detection of gene variants in FV Leiden, FII G20210A, MTHFR C677T, and PAI-1 4G/5G was carried out by real-time PCR on an SaCycler-96 Real-Time PCR System (model SaCycler-96 RUO, Sacace Biotechnologies, Italy). The following commercial kits

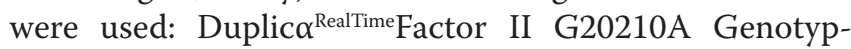

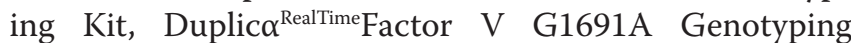
Kit, Duplica ${ }^{\text {RealTime }}$ MTHFR C677T Genotyping Kit, and

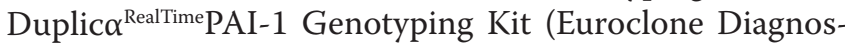
tica, Italy). Each of these kits was designed to identify the mentioned gene variants using two provided reaction mixes, the amplification mix (with Hot Start Taq DNA polymerase, nucleotides, $\mathrm{MgCl}_{2}$ and buffer) and the oligo mix (with primers and fluorogenic probes), according to the manufacturer's instructions.

Based on specific recognition and amplification of the target sequences by PCR, normal and mutated alleles were separated. In general, the probes designed to detect the wild-type and mutated alleles were labelled at the 5 ' end with the fluorophores FAM and HEX, respectively. The results were interpreted based on the presence of only FAM signal (homozygous wild type), only HEX signal (homozygous mutant), or both signals (heterozygous).

The summary data, which considered the presence of previous thrombotic events, pregnancy complications, demographic factors and genetic analysis results, were collected and inserted into a Microsoft Office Excel file. The statistical analysis was performed using SPSS Inc/ PASW Statistics 18 for Windows (SPSS, Chicago, USA). The possible relations between PL and genetic variants were tested using the Wilcoxon test. Deviation from HWE for each group of genotypes was analysed using the HWE calculator (http://www.oege.org/software/ hwe-mr-calc.shtml), with $X^{2}<3.84$ and the accepted significance at $\mathrm{p}<0.05$. The prevalence of each variant was compared with the data from the control group, a healthy Serbian population with previously published gene frequencies $(5,17,18)$, using the chi-square test with a $95 \%$ confidence interval (CI) and significance at $\mathrm{p}<0.05$. Multivariate binary logistic regression analysis was used to examine the significant predictors of previous miscarriages.

\section{RESULTS}

In the studied group of 87 patients with hereditary thrombophilia, there were 161 pregnancy losses, and 52 of the patients reported recurrent abortions (with a maximum of 6 recorded spontaneous abortions in one woman). In 21 cases, IUFD was present with pregnancy loss. The mean number of adverse pregnancy outcomes (spontaneous abortions + IUFD) was $1.89 \pm 0.89$.

The most commonly mutated alleles present in the study population were $4 \mathrm{G}$ of the PAI-1 gene $(60.92 \%$, $106 / 174$ alleles) and the $\mathrm{T}$ allele of the MTHFR gene (47.13\%, 82/174 alleles). The frequencies of mutant FVL and FII G20210A alleles were 9.77\% (17/174) and 2.87\% $(5 / 174)$, respectively (Table 1$)$.

Based on the measured and expected allelic and genotype frequencies of the variants FV Leiden G1691A, FII G20210A, MTHFR C677T and PAI-1 4G/5G, it was found that the population did not deviate from HWE (Table 1).

The estimated frequencies of mutated alleles in the analysed group of patients were all higher than those in the healthy control population in Serbia, but the chi-square test showed that only the increased presence of the mutated FV Leiden and MTHFR alleles was statistically significant ( $\mathrm{p}<0.001$ and $\mathrm{p}<0.01$, respectively) (Figure 1 ).

Table1. The genotypes' and allelic frequencies of inherited trombophilic risk factors in the analyzed group of women with pregnancy complications from Central Serbia

\begin{tabular}{|c|c|c|c|c|c|c|c|}
\hline \multirow{4}{*}{$\begin{array}{c}\text { Genes } \\
\text { Factor V }\end{array}$} & \multicolumn{3}{|c|}{ The genotypes } & \multirow{2}{*}{\multicolumn{2}{|c|}{$\begin{array}{c}\text { Allelic } \\
\text { Frequency (\%) }\end{array}$}} & \multicolumn{2}{|c|}{ Deviation from HWE } \\
\hline & \multirow{2}{*}{$\begin{array}{c}\begin{array}{c}\text { Wild type } \\
(\%)\end{array} \\
\text { G/G }\end{array}$} & \multirow{2}{*}{$\begin{array}{c}\text { Heterozygote } \\
(\%)\end{array}$} & \multirow{2}{*}{$\begin{array}{c}\text { Homozygote } \\
(\%)\end{array}$} & & & $\mathrm{X}^{2}$ & $P$ \\
\hline & & & & Wild type G & Mutated A & \multirow{2}{*}{$1.17^{*}$} & \multirow{2}{*}{0.2800} \\
\hline & 80.56 & 19.54 & 0.0 & 90.23 & 9.77 & & \\
\hline \multirow{2}{*}{ Factor II } & G/G & G/A & $\mathrm{A} / \mathrm{A}$ & Wild type $\mathrm{G}$ & Mutated A & \multirow{2}{*}{$0.09^{*}$} & \multirow{2}{*}{0.7612} \\
\hline & 94.25 & 5.75 & 0.0 & 97.13 & 2.87 & & \\
\hline \multirow{2}{*}{ MTHFR } & $\mathrm{C} / \mathrm{C}$ & $\mathrm{C} / \mathrm{T}$ & $\mathrm{T} / \mathrm{T}$ & Wild type C & Mutated T & \multirow{2}{*}{1.52} & \multirow{2}{*}{0.2182} \\
\hline & 31.03 & 43.68 & 25.29 & 52.87 & 47.13 & & \\
\hline \multirow[b]{2}{*}{ PAI-1 } & $5 \mathrm{G} / 5 \mathrm{G}$ & $5 G / 4 G$ & 4G/4G & Wild type 5G & Mutated 4G & \multirow{2}{*}{$3.19^{*}$} & \multirow{2}{*}{0.0885} \\
\hline & 19.54 & 39.08 & 41.38 & 39.08 & 60.92 & & \\
\hline & & & & & & & \\
\hline
\end{tabular}

* HWE received for value of $X^{2}<3.84 ; P<0.05$ for one degree of freedom $-1 \mathrm{df}$ 


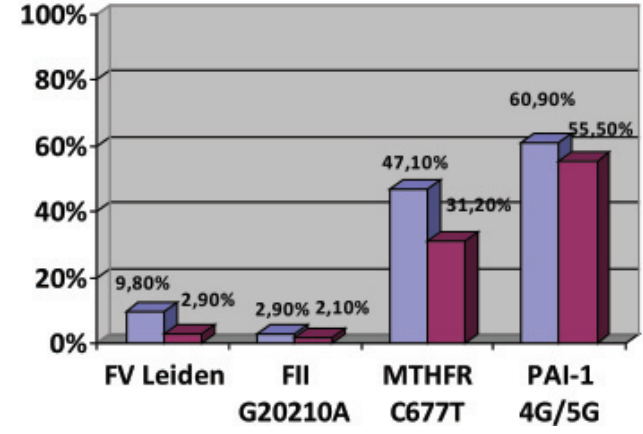

Figure 1. Comparison of allelic frequencies in the analyzed group of patients and healthy population

The most common genotypes with mutant alleles were for the variants $4 \mathrm{G} / 5 \mathrm{G}$ in the PAI-1 gene (80.46\%: $39.08 \%$ heterozygous and $41.38 \%$ homozygous) and C677T in the MTHFR gene (25.29\% heterozygous and $43.68 \%$ homozygous) (Table 1). Statistically higher genotype frequencies in the study population than in the healthy population in Serbia were observed for all the variants except G20210A in the FII gene.

In $35.63 \%$ of the cases in the analysed group of patients $(31 / 87)$, only one mutated variant was present. The rest of the patients carried different combinations of compound genotypes, with 4 types being observed in more than one case (Figure 2). The dominant combination of genetic variants was PAI-1 4G/5G + MTHFR C677T (45.98\%, 40/87) (Figure 2).

In the group of patients with recurrent abortions, the most frequent combination was the presence of the double variants PAI-1 4G/5G + MTHFR C677T (46.15\%, 24/52).

The Wilcoxon test showed only a weak positive correlation between miscarriages and the MTHFR C677T

Table 2. Multivariate Binary Logistic Regression analysis of influence of examined genetic factors on pregnancy loss

\begin{tabular}{lll}
\hline \multirow{2}{*}{ Examined risk factors } & \multicolumn{2}{l}{ Multivariate analysis } \\
\cline { 2 - 3 } FV Leiden & ${ }^{+}$OR $\left(\mathbf{9 5 \%}{ }^{\ddagger} \mathbf{C I}\right)$ & $\mathbf{P}$ \\
FII G20210A & $0,337(0,069-1,630)$ & 0,176 \\
MTHFR C677T & $0,187(0,020-1,712)$ & 0,138 \\
PAI-1 4G/5G & $2,482(1,006-6,124)$ & $0,049^{*}$ \\
\hline
\end{tabular}

"statistically significant $P<0.05$; ${ }^{\dagger}$ odds ratio; $\neq$ confidence interval;

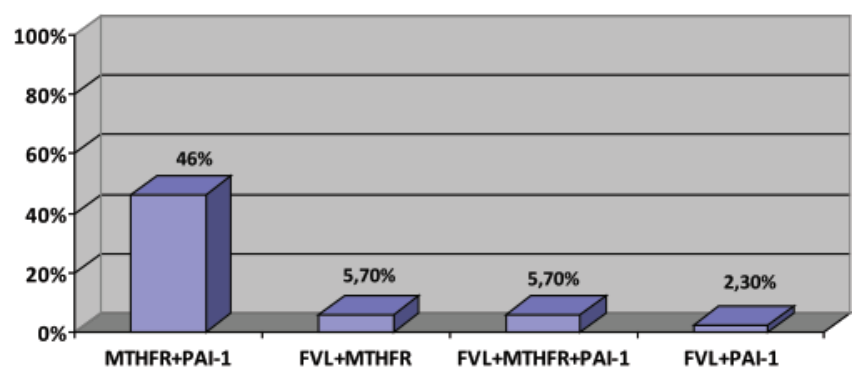

Figure 2. The most frequent compound genotypes (homozygous and/or heterozygous) in the analyzed group of patients from Central Serbia variant $\left(0.217^{*}, P<0.05\right)$. The impact of all four variants in the analysed group of patients with PL with/without IUFD was determined by multivariate binary logistic regression analysis. The results showed that the variants $4 \mathrm{G} / 5 \mathrm{G}$ in the PAI-1 gene (OR 0.364; 95\% CI 0.134-0.973, $P<0.05$ ) and C677T in the MTHFR gene (OR 2.482; 95\% CI 1.006$6.124, P<0.05)$ were segregated as significant predictors of the frequent occurrence of miscarriages (Table 2).

\section{DISCUSSION}

Based on the estimated allelic frequencies of the four most commonly analysed variants worldwide (FV Leiden G1691A, FII G20210A, MTHFR C677T and PAI-1 4G/5G) in a population of women from Central Serbia with inherited thrombophilia who experienced a pregnancy loss, it was determined that the tested population was in genetic equilibrium. The most prevalent compound genotype in this study group was a combination of PAI-1 4G/5G + MTHFR C677T (46.15\%), which was found to be the only significant predictor of common previous miscarriages.

Pregnancy is characterized by hypercoagulable states and microalbuminuria (1). In pregnancy, numerous changes in the haemostatic system, including an increased concentration of certain coagulation factors, a reduction in the concentration of natural inhibitors of coagulation, lower fibrinolytic activity, and slow flow of blood in the venous system of the lower limbs due to compression of the enlarged uterus, all contribute to the increased susceptibility to blood clotting $(1,10)$.

Successful pregnancy outcomes depend on adequate placental vascularization, and its damage is part of the various pathophysiologies of pregnancy complications. Physiological changes in coagulation and fibrinolysis during pregnancy may react with inherited and acquired thrombophilia states, placing these patients at a higher risk of pregnancy complications $(9,11)$.

The incidence of recurrent abortions is estimated to be $15-20 \%$, and in $50 \%$ of the cases, the causes remain unexplained (12). According to data in the literature, pregnant women with thrombophilia, both congenital and acquired, have a higher incidence of RPL $(5,13)$. Inherited or acquired thrombophilia has been diagnosed in $50 \%$ to $65 \%$ of women with a history of unexplained foetal loss (14).

The single mutation in the gene for FV Leiden is a substitution of glutamine with arginine at position 506, which is known to be a cause of resistance to APC. This mutation results in increased production of thrombin and leads to hypercoagulability (15). Resistance to APC caused by this mutation is found in $20-40 \%$ of patients with venous thrombosis and in $60 \%$ of women with thrombosis, which occurs during pregnancy (15). Based on the conducted studies, the risk of thromboembolism was found to be increased 5-10 times in heterozygous carriers of the mutation, whereas the risk in homozygous carriers was increased 80-100 times (16). The mutation 
in FVL is present in $5-12 \%$ of the general population. In our studied population, the allelic frequency of the FV G1691A variant was $9.77 \%$, which was significantly higher than that in the healthy population in Serbia $(2.9 \%)$ (17), consistent with the findings among women with recurrent foetal loss (RFL) in northern Serbia (9.5\%) (18). Madjunkova et al. (19) reported the frequency of the mutated allele A in women with miscarriages in Slovenia (2.6\%), Macedonia (3.8\%) and Albania (2.7\%), as well as the overall prevalence in all three groups $(2.8 \%)$; these values were lower than those in our study. In our study, the presence of homozygous carriers of the FVL mutation was not detected, whereas heterozygous carriers were present in $19.54 \%$ of the cases, almost 6 times more often than in the recorded data (5.8\%) for the healthy Serbian population (17). The observed presence of the mutated allele in our study is consistent with the results of other studies; for example, in Turkey, Isaoglu et al. did not find any homozygous carriers of this mutation, whereas there were $21.7 \%$ heterozygous carriers among women with RPL (20).

The variant G20210A is located in the 3' noncoding region of the FII gene, and it is associated with elevated levels of prothrombin in the blood $(4,16)$. Its presence increases the risk of deep vein thrombosis by approximately three fold $(4,15)$. Madjunkova et al. reported that the frequency of the FII G20210A gene variant among women with pregnancy loss was $1.5 \%$ in Slovenia, 3.8\% in Macedonia and $3.6 \%$ in Albania. The overall prevalence in these three groups was $2.4 \%$ (19), which is similar to the observed prevalence of the mutated allele FII G20210A in the group of women with pregnancy loss in this study (2.87\%). Moreover, the prevalence of the mutated allele FII G20210A in our subjects was not different from that in the healthy population in Serbia and the general worldwide population $(2.87$ vs. $2.1 \%$ and $2-3 \%$, respectively) $(17,20)$. The same observation was made concerning the frequency of heterozygous carriers, which was not significantly higher than that in the healthy Serbian population and the general worldwide population ( $5.75 \%$ vs. $5.75 \%$ and $4.2 \%$, respectively) (17, $20)$, and it was similar to that among women with recurrent foetal loss in the northern regions of Serbia (7\%) (18). The results are in agreement with the data from other studies done in Turkey $(21,22)$.

The variant C677T in the MTHFR gene leads to the synthesis of the thermolabile form of the enzyme methylenetetrahydrofolate reductase ( $t$-MTHFR), resulting in reduced synthesis of derivatives of folate for the remethylation of homocysteine to methionine and reduced folate intake. This process leads to hyperhomocysteinemia and increases the risk of venous thrombosis $(4,20)$. The estimated frequency of the mutated allele in our study population was $47.13 \%$, which was significantly higher than that in the healthy group (31.2\%) in the study by Djordjevic et al. (17). The observed presence of the mutated $\mathrm{T}$ allele in the population of women with pregnancy loss in Slovenia
(38.3\%), Macedonia (46.2\%) and Albania (44.5\%), as well as the overall prevalence in these three populations (41.2\%), was similar or lower than the observed allelic frequencies in our study. Heterozygous and homozygous carrier genotypes were also more frequent in the analysed group of women with pregnancy loss than in the data for the healthy Serbian population provided by Djordjevic et al. (17) $(43.68 \%$ vs. $39.2 \%$ and $25.3 \%$ vs. $11.2 \%$, respectively). A similar or lower frequency was found in other populations $(20,21)$.

Mutated allelic variant 4 guanosine (4G) in the promoter of the PAI-1 gene at position 675 bp contains binding sites for only activators of transcription, in contrast to the normal allele, $5 \mathrm{G}$, leading to elevated levels of PAI-1 in the blood and reduced fibrinolysis (5). The PAI-1 4G/5G genetic variant could be a risk factor for deep vein thrombosis, spontaneous abortions and preeclampsia (5). The frequency of the mutated PAI-1 4G allele (60.92\%) was higher in our study than in the data for the healthy population in Serbia (55.49\%) provided by Djordjevic et al. (5). In addition, the frequency of the mutated PAI-1 4G allele in the observed population was higher than that in the study by Madjunkova et al. (19), which included women with pregnancy loss in Slovenia (43.8\%), Macedonia (42.5\%), and Albania (43.6\%), as well as the overall prevalence in all three groups (56.5\%). The frequency of PAI-1 4G/4G genetic variant carriers in the population of women with pregnancy loss in the present study (41.38\%) was higher than that in the study by Djordjevic et al. (5) ainvolving a healthy Serbian population (34.76\%). Additionally, the frequency of PAI-1 4G/4G genotype carriers was higher in the present study than in a group of women with habitual abortion and miscarriages in different populations, for example, Polish and Iranian populations (23-25). The frequency of $39.08 \%$ heterozygous and $41.38 \%$ homozygous for the PAI-1 4G/5G variant in the population of women with PL in the present study was even higher than that in the study of foetal loss among women from other Serbian regions (26).

In the studies of habitual abortions carried out in different populations, Isaoglu et al. (21) found a statistically significant correlation between factor $\mathrm{V}$ Leiden and early and late RPL and between prothrombin G20210A and early RPL. Although the results of various analyses are often in conflict, the most commonly observed associations refer to the relationship between RPL and FV Leiden and FII G20210A gene variants (27). The results of Li et al.'s (28) meta-analysis showed a significant connection between the gene variant PAI-1 4G/5G and RPL. $\mathrm{Li}$ et al. (28) found that in the subgroup analysis by race, the PAI-1 4G/5G gene variant was associated with an increased risk of RPL in a Caucasian population, but the association was not observed in Asians. Shakar et al. (24) found that compared to the control group, carriers of $4 \mathrm{G}$ homozygous mutations were significantly more prone to RPL. The lack of a connection between C677T MTHFR and PL was reported by Dutra et al. (29). In the meta- 
analysis by $\mathrm{Wu}$ et al. (30), the results among Caucasians did not suggest an association between C677T MTHFR and RPL. This meta-analysis supports the idea that the MTHFR C677T genotype is associated with an increased risk of RPL, except in Caucasians (30). Li Luo et al. (31) found that the MTHFR C677T allele and the C677T haplotype were risk factors for RPL among a Han Chinese population. Ivanov et al. (32) found a weak association between $\mathrm{T}$ allele carrier status (both in the homozygous and heterozygous states) in Bulgarian women and recurrent embryonic lossT. The MTHFR C677T genetic variant is frequently present in the homozygous and heterozygous forms in the general Caucasian population (33). It is considered that the MTHFR polymorphism does not predispose to HHC when the folate status is sufficient (33). In combination with vitamin deficiency, heterozygotes for MTHFR have mildly increased homocysteine concentrations (33). In accordance with previous knowledge, the MTHFR C677T variant could be considered an agent for RPL in only combination with other risk factors influencing foetal development (33). In this research, we found a weak positive correlation between MTHFR C677T and RPL, which indicates that this variant should be investigated along with other thrombophilic mutations and accordingly interpreted.

Ozdemir et al. (34) found that homozygosity of 4G in PAI-1 and MTHFR C677T in Turkish women with RPL plays a crucial role and should be considered a risk factor for RPL. In the analysed group of patients with pregnancy complications in our study, 52 had recurrent spontaneous abortions. The most prevalent compound genotype was a combination of PAI-1 4G/5G + MTHFR C677T (46.15\%), which was a significant predictor of common previous miscarriages.

\section{CONCLUSION}

In a group of women with spontaneous abortions with or without IUFD in the region of Central Serbia, there is an increased frequency of mutated FVL alleles and MTHFR C677T and an increased frequency of homozygous/heterozygous carriers of FV Leiden G1691A, MTHFR C677T and PAI-1 4G/5G variants. The finding of a weak positive correlation between MTHFR C677T and RPL in this study indicates that this variant is significant, along with the other thrombophilic mutations, and highlights certain dietary habits in this region, for example, low folate intake, as well as the importance of folate supplementation prior to pregnancy, particularly in women who are carriers of the MTHFR C677T variant.

In this research, we found dominance of the compound genotype PAI-1 4G/5G + MTHFR C677T in a group of women with pregnancy loss in Central Serbia, which was found to be the only significant predictor of common previous miscarriages, and showed their synergistic effect on the loss of pregnancy complicated by thrombophilia.

\section{ACKNOWLEDGMENTS}

This research was financed according to the contract of realization of the scientific research project "Micronuclei frequency in peripheral blood lymphocytes in pregnant women with thrombophilia" (evident number JP 02/15) from the Basic Research Program of the Faculty of Medical Sciences in Kragujevac for 2015 (evident number 05-10599).

\section{DECLARATION OF INTEREST}

The authors report no conflicts of interest. The authors alone are responsible for the content and writing of this article.

\section{REFERENCES}

1 Mitić G, Považan L, Lazić R, Spasić D, Maticki-Sekulić M. Deficiency of the natural anticoagulantproteins in women with related venous thromboembolism. Med pregl. 2009; 62(1-2):53-62.

2 Stevens SM, Woller SC, Bauer KA, et al. Guidance for the evaluation and treatment of hereditary and acquired thrombophilia. Journal of Thrombosis and Thrombolysis. 2016; 41:154-164.

3 Versteeg HH, Heemskerk JW, Levi M, Reitsma PH. New fundamentals in hemostasis. Physiol Rev. 2013; 93(1):327-358.

4. Đorđević V, Rakićević LB, Spasić M, Miljić P, Miković D, Kovač M, et al. Factor V Leiden, FII G20210A, MTHFR C677T mutations as risk factors for venous thrombosis during pregnancy and puerperium. Vojnosanit pregl. 2005; 62(3):201-205.

5 Đorđević V, Gvozdenov M, Pruner I, Tomić B, Kovač M, Antonijević N, et al. The prevalence of PAI-1 4G/5G gene variant in Serbian population. Medicinski glasnik. 2013;18(49):28-41.

6 Đorđević V, Pruner I, Radojković D. Molecular basis of thrombophila. J Med Biochem 2014;33(1):22-7.

7 ClinVar [page on the internet]. Bethesda, U.S: National Center for Biotechnology Information National Library of Medicine, [Cited 2017 November]. Available from: https://www.ncbi.nlm.nih.gov/clinvar/

8 Sparić R, Lazović B, Stajić Z, Mazić S, Đelić M, Kadija S. Thromboembolic complications during pregnancy and delivery. Med pregl. 2013;66(9-10):417-423.

9 Simcox LE, Ormesher L, Tower C, Greer IA. Thrombophilia and Pregnancy Complications. Int J Mol Sci. 2015;16(12):28418-28428.

10 Husar D, Đelmiš J. Thrombophilia and its influence on the pregnancy outcome. Perinatol. 2008;17(3):150-156.

11 Mitić G, Novakov-Mikić A, Považan L, Mitreski A, Kopitović V, Vejnović T. Thromboprophylaxis implementation during pregnancy in women with recurrent fetal losses and thrombophilia. Med pregl. 2011; 64(910):471-475. 
12 Ford HB, Schust DJ. Recurrent Pregnancy Loss: Etiology, Diagnosis, and Therapy. Reviews in Obstetrics and Gynecology. 2009; 2(2):76-83.

13 Mazzucconi MG, De Sanctis V, Alfò M, Amendolea MA, Conti L, Santoro C, Baldacci E, Peraino M, Masala C. Maternal thrombophilia and adverse pregnancy outcome: a case-control study. Acta Haematol. 2015;133(2):242-248.

14 Mitic G, Kovac M, Povazan L, Magic Z, Djordjevic V, Salatic I, Mitic I, Novakov-Mikic A. Inherited thrombophilia is associated with pregnancy losses that occur after 12th gestational week in Serbian population. Clin Appl Thromb Hemost. 2010 Aug;16(4):435-9

15 Đorđević V, Pruner I, Rakičević L, Kovač M, Miković D, Miljić P, et al. FV Leiden, FII G20210A and MTHFR C677T mutations in patients with lower or upper limb deep vein thrombosis. Genetika. 2011;43(2):371-380.

16 Cunningham FG, Leveno KJ, Bloom SL, Hauth JC, Rouse DJ, Spong CY, editors. Williams Obstetrics. 23rd edition. United States of America: The McGraw-Hill Companies, Inc. 2010.1385p.

17 Djordjevic V, Rakicevic LJ, Mikovic D, Kovac M, Miljic P, Radojkovic D, Savic A. Prevalence of factor V leiden, factor V cambridge, factor II G20210A and methylenetetrahydrofolate reductase C677T mutations in healthy and thrombophilic Serbian populations. Acta Haematol. 2004;112(4):227-229.

18 Kovac M, Mitic G, Mikovic Z, Djordjevic V, Savic O, Mandic V, Rakicevic LJ, Antonijevic N, Radojkovic D. Thrombophilia in women with pregnancy-associated complications: fetal loss and pregnancy-related venous thromboembolism. Gynecol Obstet Invest. 2010;69(4):233-238.

19 Madjunkova S, Volk M, Peterlin B, Plaseska-Karanfilska D. Detection of Thrombophilic Mutations Related to Spontaneous Abortions by a Multiplex SNaPshot Method. Genetic Testing and Molecular Biomarkers. 2012;16(4):259-264.

20 Elezović I. Role of gene polymorphism in development of thromboses. Srp Arh Celok Lek. 2006;134 Suppl 1:64-71.

21 Isaoglu U, Ulug P, Delibas IB, Yilmaz M, Kumtepe Y, Dogan $\mathrm{H}$, et al. The association between inherited thrombophilia and recurrent pregnancy loss in Turkish women. Clin Exp Obstet Gynecol. 2014;41(2):177-181.

22 Ocak Z, Özlü T, Ozyurt O. Association of recurrent pregnancy loss with chromosomal abnormalities and hereditary thrombophilias. African Health Sciences. 2013;13(2):447-452.

23 Khosravi F, Zarei S, Ahmadvand N, Akbarzadeh-Pasha Z, Savadi E, Zarnani AH, et al. Association be- tween plasminogen activator inhibitor 1 gene mutation and different subgroups of recurrent miscarriage and implantation failure. J Assist Reprod Genet. 2014;31(1):121-124.

24 Shakarami F, Akbari MT, Zare Karizi S. Association of plasminogen activator inhibitor-1 and angiotensin converting enzyme polymorphisms with recurrent pregnancy loss in Iranian women. Iranian Journal of Reproductive Medicine. 2015;13(10):627-632.

25 Kurzawińska G, Barlik M, Drews K, Różycka A, Seremak-Mrozikiewicz A, Ożarowski M, Klejewski A, Czerny B, Wolski H. Coexistence of ACE (I/D) and PAI-1 (4G/5G) gene variants in recurrent miscarriage in Polish population. Ginekol Pol. 2016; 87(4):271-276.

26 Djordević V, Gvozdenović M, Pruner I, Mirjana Kovač M, Tomić B, Stanković M, Dragica Radojković D. The prevalence of PAI-1 4G/5G polymorphism in women with fetal loss-first data for a Serbian population J Med Biochem. 2014;33:203-207.

27 Liatsikos SA, Tsikouras P, Manav B, Csorba R, von Tempelhoff GF, Galazios G. Inherited thrombophilia and reproductive disorders. J Turk Ger Gynecol Assoc. 2016;17(1):45-50.

28 Li X, Liu Y, Zhang R, Tan J, Chen L, Liu Y. Meta-Analysis of the Association between Plasminogen Activator Inhibitor-1 4G/5G Polymorphism and Recurrent Pregnancy Loss. Med Sci Monit. 2015;21:1051-1056.

29 Dutra CG, Fraga LR, Nácul AP, Passos EP, Gonçalves RO, Nunes OL, De Godoy BA, Leistner-Segal S, Vianna FS, Schüler-Faccini L, Sanseverino MT. Lack of association between thrombophilic gene variants and recurrent pregnancy loss. Hum Fertil (Camb). 2014;17(2):99-105.

$30 \mathrm{Wu}$ X, Zhao L, Zhu H, He D, Tang W, Luo Y. Association between the MTHFR C677T polymorphism and recurrent pregnancy loss: a meta-analysis. Genet Test Mol Biomarkers. 2012;16(7):806-811.

31 Luo L, Chen Y, Wang L, et al. Polymorphisms of Genes Involved in the Folate Metabolic Pathway Impact the Occurrence of Unexplained Recurrent Pregnancy Loss. Reproductive Sciences. 2015;22(7):845-851.

32 Ivanov P, Gecheva S, Tsvyatkovska T, Izmailov A, Komsa-Penkova R, Kovacheva K, Konova E, Simeonova M, Tanchev S. A weak association of $677 \mathrm{C}>\mathrm{T}$ polymorphism in MTHFR with recurrent embryonic loss [Article in Bulgarian] Akush Ginekol (Sofiia). 2014;53(1):8-12.

33 Margetić S. Laboratory investigation of thrombophilia. J Med Biochem. 2014;33:28-46.

34 Ozdemir O, Yenicesu GI, Silan F, Köksal B, Atik S, Ozen F, Göl M, Cetin A. Recurrent pregnancy loss and its relation to combined parental thrombophilic gene mutations. Genet Test Mol Biomarkers. 2012;16(4):279-286. 